\title{
ОСОБЕННОСТИ ОТВЕТСТВЕННОСТИ ЗА НЕЗАКОННОЕ ИСПОЛЬЗОВАНИЕ ПЕРСОНАЛЬНЫХ ДАННЫХ ФИЗИЧЕСКИХ ЛИЦ
}

\section{FEATURES OF RESPONSIBILITY FOR THE ILLEGAL USE OF PERSONAL DATA OF INDIVIDUALS}

\section{Vilisova}

Summary. This article examines the current state of responsibility for the illegal use of personal data, will describe the legislative provisions that relate to the legal status in the Russian legislation, will consider the issues of criminal classification, will draw distinctions with related elements of crimes. An analysis of Russian legal acts, as well as educational and scientific literature, shows that there are problems with the correct qualification of the actions of persons who are involved in the illegal use of personal data. The purpose of the article is to analyze the responsibility for the illegal use of personal data of individuals.

Keywords: criminal liability, personal data, individuals.

\author{
Вилисова Ирина Борисона \\ Аспирант, Уральский институт управления - \\ филиал РАНХИГC \\ vilisova_i@mail.ru
}

Аннотация. В настоящей статье рассматривается актуальное состояние ответственности за незаконное использование персональных данных, будут охарактеризованы законодательные положения, которые касаются правового статуса в российском законодательстве, будут рассмотрены вопросы уголовно-правовой классификации, проведутся разграничения со смежными составами преступлений. Анализ российских нормативно-правовых актов, а также учебной и научной литературы показывает, что существуют проблемы правильной квалификации действий лиц, которые причастны к незаконному использованию персональных данных. В частности, это касается должностных лиц, которые в силу собственных служебных полномочий и занимаемого положения имеют доступ к персональным данным. Целью статьи является анализ ответственности за незаконное использование персональных данных физических лиц.

Ключевые слова: уголовная ответственность, персональные данные, физические лица.

которые получают доступ к конфиденциальной информации.

Человеческий фактор выражается к незаконному использованию данных физических лиц со стороны лиц, которым данная информация была доверена в силу должностных полномочий. К таковым, в частности, относятся сотрудники органов внутренних дел, у которых имеются интегрированные базы данных, в которых сосредоточены паспортные данные о физических лицах, которые проживают на территории российского государства. Отдельные сведения, которые составляют персональные данные, содержатся в базах данных иных органов государственной власти.

\section{Обзор ^итературы}

Защита частной жизни признается приоритетным направлением любого государства. Это подтверждается на международно-правовом уровне. Так, статьей 12 Всеобщей декларации прав человека подчеркивается запрет на проникновение в частную жизнь отдельно взятого человека.

Статья 8 Конвенции о защите прав человека и основных свобод устанавливает нормативно-правовое 
положение, согласно которому личная и семейная жизнь неприкосновенна [4].

Статьей 23 Конституции РФ гарантирована защита частной жизни, личная и семейная тайна. Таким образом, законодатель относит персональные данные физических лиц к категории, защищаемых нормами права объектов [1].

Пункт 1 статьи 3 Федерального закона «О персональных данных» определяет персональные данные как любую информацию, которая прямо или косвенно относится к субъекту [3].

Как было указано в начале настоящей статьи, государством принимается комплекс мер, которые направлены на охрану персональных данных физических лиц. В Уголовном кодексе Российской Федерации (далее УК РФ) предусмотрена отдельная 19 глава, которая посвящена преступлениям против конституционных прав и свобод человека и гражданина [2]. Отдельно защите персональных данных посвящена статья 137 УК РФ.

В качестве объекта преступления мы рассматриваем общественные отношения, которые складываются в частной жизни лица. Данные отношения могут составлять его личную и семейную тайну.

Объективная сторона предполагает совершение альтернативных действий, среди которых мы можем выделить следующие:

- собирание;

- распространение.

Под собиранием мы можем понимать комплекс незаконных мер и действий, которые направлены на накоплении информационных данных о том или ином физическом лице. Методами и способами собирания могут выступать различные действия - беседы, видеосъемка, фотоснимки и т.п.

Распространение представляет собой незаконное разглашение персональных данных о физических лицах. При таком раскладе конфиденциальная информация становится известна неопределенному кругу лиц. Также распространение может осуществляться с использованием средств массовой информации, что, в свою очередь, образует квалификационный состав рассматриваемого нами преступления [4].

Субъект данного преступления подразделяется на два вида:

- общий, к которому можно отнести физическое лицо, которое достигло шестнадцатилетнего возраста;
- специальный, под которым подразумевается лицо, которое наделено соответствующими должностными полномочиями [4].

Субъективная сторона рассматриваемого нами состава преступления отличается прямым умыслом.

Состав ст. 137 УК РФ является формальным, т.е. оно считается завершенным независимо от наступления каких-либо материальных последствий.

\section{Метолы исслеАования}

В ходе настоящего исследования нами были задействованы общенаучные и частнонаучные методы. Среди них мы можем выделить эмпирическое наблюдение, анализ и сравнение.

\section{Результаты и Аискуссия}

В правоприменительной практике основной вопрос в квалификации незаконного использования персональных данных физических лиц заключается в отграничении состава преступления, предусмотренного ст. 137 УК РФ, от состава преступления, которое предусмотрено ст. 285 УК РФ и заключается в злоупотреблении должностным положением из корыстной, личной и иной заинтересованности.

Вышеназванные составы преступлений обладают рядом общих черт:

- совершение преступления специальным субъектом - должностным лицом;

- нарушение неприкосновенности личной жизни как одного из основных конституционных прав граждан;

- незаконный характер;

- использование должностного положения для получения персональных сведений;

- личная заинтересованность [4].

Тем не менее, в качестве основного критерия, на основе которого мы проводим разграничения между вышеуказанными составами преступлений, выступает корыстный мотив, который присутствует при злоупотреблении должностным положением, а при незаконном собирании и распространении сведений о частной жизни отсутствует. Корыстный мотив выражается в получении денежного вознаграждения, материальных благ или имущественных прав.

\section{Выво $\triangle \mathrm{b}$}

Как мы видим, между уголовно наказуемыми деяниями проходит тонкая грань, которую органам судебной 
власти и правоохранительным органам следует учитывать при юридической квалификации. Нами видится необходимым осуществить четкое законодательное регламентирование уголовных правоотношений, которые имеют место в сфере защиты конституционных прав и свобод граждан.

\section{ЛИТЕРАТУРА}

1. Конституция Российской Федерации (принята всенародным голосованием 12.12.1993) (с учетом поправок, внесенных Законами РФ о поправках к Конституции РФ от 30.12.2008 N6-ФК3, от 30.12.2008 N7-ФК3, от 05.02.2014 N2-ФК3, от 01.07.2020 N11-ФК3) // Собрание законодательства РФ, 01.07.2020, N31, ст. 4398.

2. Уголовный кодекс Российской Федерации от 13 июня 1996 года № 63-Ф3 (ред. от 08.04.2021 г.) // Собрание законодательства РФ.— 1996.— № 25, ст. 2954.

3. Федеральный закон от 27.07.2006 № 152-Ф3 «0 персональных данных» (ред. от 31.12.2017) // Собрание законодательства РФ. 2006. № 31 (1 ч.). Ст. 3451.;

4. Уголовное право России. Часть Особенная: учебник / под. ред. Л.Л. Кругликова. — М.: Проспект. 2018. — 816 с.

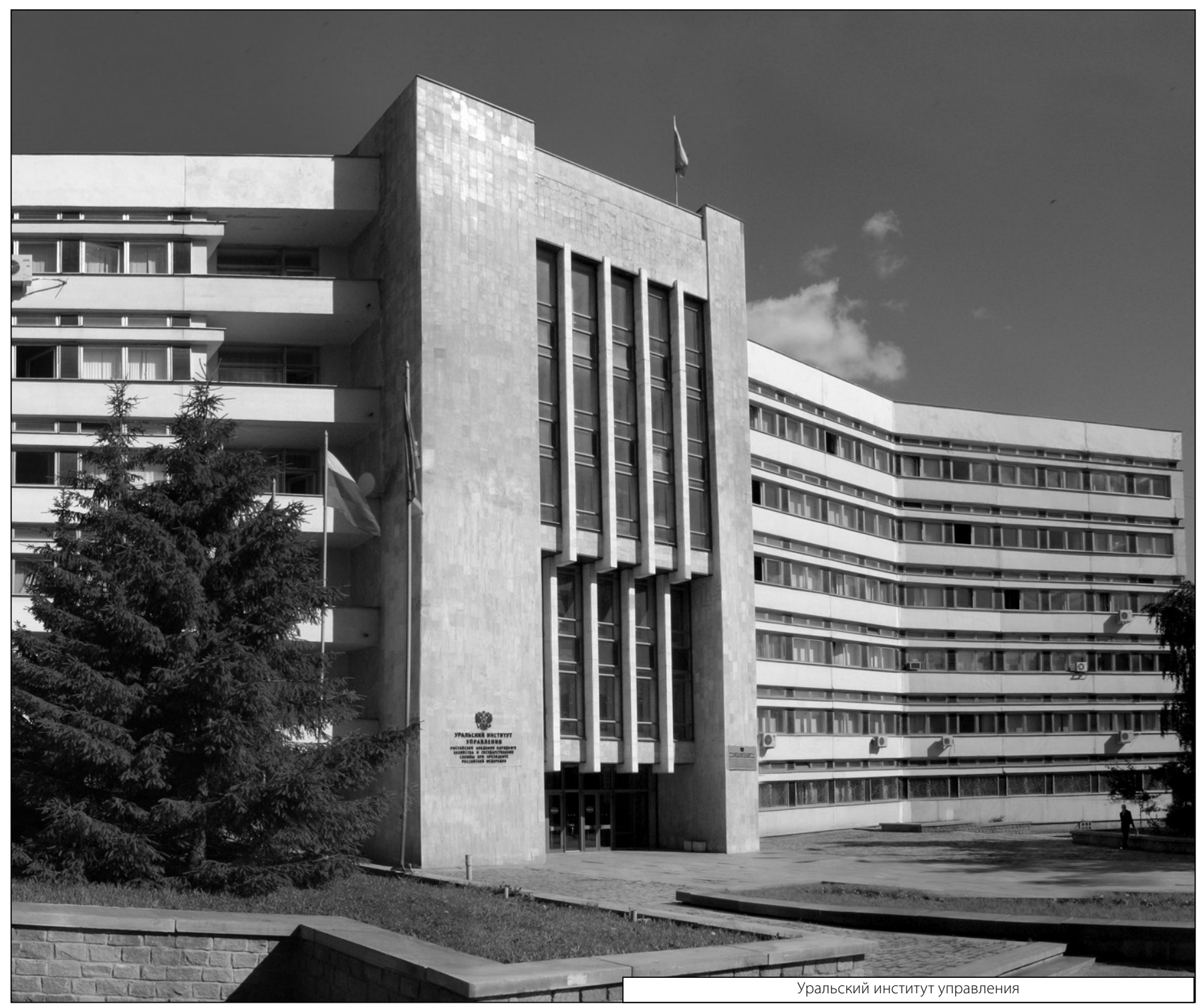

